\title{
Tall fescue as an alternative to timothy fed with or without alfalfa to dairy cows
}

\author{
A.-M. Richard, ${ }^{1}$ R. Gervais, ${ }^{1} \oplus$ G. F. Tremblay, ${ }^{2}$ ๑ G. Bélanger,${ }^{2} \odot$ and É. Charbonneau ${ }^{1 *}$ ๑( \\ ${ }^{1}$ Département des sciences animales, Université Laval, Québec, QC, Canada G1V 0A6 \\ ${ }^{2}$ Québec Research and Development Centre, Agriculture and Agri-Food Canada, Québec, QC, Canada GIV 2J3
}

\begin{abstract}
Tall fescue might be an alternative to timothy in northeastern North America because of its tolerance of recurring drought periods and its good summer regrowth, but is not always considered as an option in dairy rations because of its possible lack of palatability. The objective of this study was to evaluate the effects on the performance of lactating dairy cows of (1) replacing timothy silage by tall fescue silage, offered as sole forage in the diet or in combination with alfalfa silage, and (2) feeding tall fescue as silage (35\% dry matter, DM) or haylage $(55 \%$ DM). Experimental diets with a forage-to-concentrate ratio of 70:30 were (1) $100 \%$ timothy silage (TS); (2) 100\% tall fescue silage (TFS); (3) 55:45 timothy:alfalfa silages (TS + AS); (4) 55:45 tall fescue:alfalfa silages (TFS + AS); and (5) 100\% tall fescue haylage (TFH). Fifteen Holstein cows in midlactation ( 5 fitted with a rumen fistula) were randomly assigned to treatments in a triple $5 \times 5$ Latin square design with treatment periods of $21 \mathrm{~d}$. Preplanned contrasts were timothy versus tall fescue silages, sole grass species versus grass-alfalfa, interaction between sole grass species and grass-alfalfa, and TFS versus TFH. Grass species did not affect dry matter intake (DMI) or milk yield and fat concentration. Milk protein concentration was not affected by grass species when offered in combination with alfalfa, but it was higher with the TS diet than the TFS diet when offered as sole forages. Adding alfalfa to either tall fescue or timothy silage resulted in greater DMI and milk yield, but lower milk fat concentration, than when the grass silages were the sole forage in the diet. The molar proportion of propionate in the rumen was greater when cows were fed diets with tall fescue silage compared with timothy silage, which resulted in a lower acetate-to-propionate ratio.
\end{abstract}

Received December 23, 2019.

Accepted April 14, 2020.

*Corresponding author: Edith.Charbonneau@fsaa.ulaval.ca
Milk fat concentrations of fatty acids from microbial origin, namely branched-chain fatty acids, were greater when grass silage, and especially timothy silage, were fed as sole forages rather than with alfalfa silage. Feeding TFH rather than TFS caused a decrease in DMI and tended to lower milk protein concentration, but did not affect milk yield. A more fibrolytic fermentation profile was observed in rumen of cows fed TFH compared with TFS, as indicated by the increase in the molar proportion of acetate and the higher acetateto-propionate ratio in rumen fluid, and a concomitant increase in branched-chain fatty acid concentration in milk fat. Tall fescue as silage or haylage is a valuable alternative to timothy silage for lactating dairy cows.

Key words: dairy cows, tall fescue, timothy, silage, haylage

\section{INTRODUCTION}

Forages in dairy cow diets of eastern Canadian farms are often a mixture of a grass species with alfalfa (Medicago sativa L.). Alfalfa-grass mixtures combine the readily available energy from grass species with the higher protein content of forage legumes, thus improving the efficiency of $\mathrm{N}$ utilization by dairy cows (Brito et al., 2008). Moreover, growing alfalfa with grasses is beneficial for both yield and nutritive value of forage crops (Bélanger et al., 2014). Timothy (Phleum pratense L.) is the main perennial forage grass species grown in mixture with alfalfa in the cool and humid region of northeastern North America. Timothy is known for its superior winter survival (Bélanger et al., 2006) and its good yield potential under cool conditions. Its regrowth, however, is poor under the warm and dry summer conditions that often occur in northeastern North America. Air temperature and water stress are predicted to increase in the near future, which could further reduce timothy regrowth (Qian et al., 2013). An air temperature increase of 2 to $3^{\circ} \mathrm{C}$ could negatively affect the productivity and the nutritive value of timothy (Bertrand et al., 2008). These changes may reduce the advantages of timothy over other forage grass species. 
Tall fescue (Schedonorus arundinacea Schreb.) is a possible alternative to timothy because of its tolerance to recurring drought periods (Peratoner et al., 2011), its good summer regrowth (Drapeau et al., 2005), and its good performance in eastern Canada when grown in mixture with alfalfa (Pomerleau-Lacasse et al., 2019). Cherney et al. (2004) compared tall fescue silage (25\% DM) to orchardgrass and alfalfa silages in dairy cow rations and found no significant difference in DMI when fed in TMR. By contrast, Johansen et al. (2017b) observed a decrease in DMI, which resulted in lower ECM yield when cows received tall fescue silage compared with other grass species, namely early perennial ryegrass and festulolium. Moreover, concerns exist about the possible lack of palatability of tall fescue in dairy rations, mainly because of its leaf roughness (Peratoner et al., 2011). Forage conservation processes have been found to decrease leaf toughness, being highest in pasture, intermediate in hay, and lowest in silage (Peratoner et al., 2011). Silages may differ in DM concentration, and information is lacking about the effects of feeding tall fescue as silage with $35 \% \mathrm{DM}$ and as haylage $(55 \%$ DM), both being commonly used on dairy farms.

Our objective was to evaluate the effect on DMI, milk production, and milk composition of lactating Holstein cows of (1) replacing timothy silage by tall fescue silage, offered as the sole forage in the diet or in combination with alfalfa silage, and (2) feeding tall fescue as silage $(35 \% \mathrm{DM})$ or haylage $(55 \% \mathrm{DM})$. We hypothesized that substituting timothy silage with tall fescue silage, fed either as sole forage or in combination with alfalfa silage, would result in similar performance of dairy cows in established lactation. We also hypothesized that the forage conservation type would not affect DMI and milk production.

\section{MATERIALS AND METHODS}

\section{Forage Production}

Tall fescue (cv. Courtenay), timothy (cv. AC Alliance), and alfalfa (cv. Genoa), established without cover crop, were grown in similar but different fields at the Centre de Recherche en Sciences Animales de Deschambault (Deschambault, QC, Canada; $46^{\circ} 40^{\prime} \mathrm{N}$, $\left.71^{\circ} 55^{\prime} \mathrm{W}\right)$. In the first year after their establishment, tall fescue and timothy were cut on Jun. 6, 2015, at the early heading stage of development, using a disk mower equipped with a roller-type conditioner and adjusted to a residual height of $10 \mathrm{~cm}$ (Discbine, model 1432, New Holland Agriculture, New Holland, PA). Timothy was wilted for $24 \mathrm{~h}$ in the field until it reached approximately $35 \%$ DM, whereas tall fescue was wilted for 24 or 30 $\mathrm{h}$ in the field until alternate rows reached respectively
$35 \%$ DM or $55 \%$ DM. Then, both timothy at $35 \%$ DM and tall fescue at 35\% DM were finely chopped and stored in plastic bag silos (Bag All, Klerk's Plastic Products Manufacturing Inc., Richburg, SC); they are hereafter referred to as timothy and tall fescue silages. Tall fescue at 55\% DM was harvested as large square bales with a baler (New Holland Agriculture square baler, model BB9060) and wrapped using a bale wrapper (Anderson Group single bale wrapper, model 780, Chesterville, QC, Canada); it is hereafter referred to as tall fescue haylage. Each large square bale of haylage was chopped before mixing of the diets using a TMR vertical mixer (V-Mix 575, Valmetal, St-Germain-deGrantham, QC, Canada) for 20 min before the mixing of the diet. Alfalfa was cut at the early bloom stage of development on Jun. 13, 2015, wilted in the field until it reached approximately $35 \%$ DM, finely chopped, and conserved in a plastic bag silo using the same procedure as for tall fescue and timothy wilted to $35 \%$ DM.

\section{Cows, Experimental Design, and Diets}

The experiment was carried out at the Centre de Recherche en Sciences Animales de Deschambault. All procedures with cows were approved by the Animal Care Committee of Université Laval (Québec, QC, Canada) in accordance with the guidelines of the Canadian Council on Animal Care (Olfert et al., 1993).

Fifteen multiparous $(3.1 \pm 1.3$ parities; mean $\pm \mathrm{SD})$ Holstein cows $(128 \pm 33$ DIM and $692 \pm 69 \mathrm{~kg}$ of BW at the beginning of the experiment), 5 of them fitted with a rumen fistula (internal diameter $10 \mathrm{~cm}$; Bar Diamond Inc., Parma, ID), were housed in a tiestall barn and fed once daily at $1000 \mathrm{~h}$. Cows were randomly assigned to treatments in a triple $5 \times 5$ Latin square design with 21 -d periods, the last $3 \mathrm{~d}$ being used for data and sample collections. Five experimental diets (70:30 forage-to-concentrate ratio) were compared: (1) $100 \%$ timothy silage (TS); (2) 100\% tall fescue silage (TFS); (3) $55 \%$ timothy silage with $45 \%$ alfalfa silage (TS + AS); (4) $55 \%$ tall fescue silage with $45 \%$ alfalfa silage (TFS + AS); and (5) 100\% tall fescue chopped haylage (TFH; Table 1). The 5 diets were adjusted based on the initial feed ingredient composition (Table 2 ) to ensure that $\mathrm{CP}$ concentration was similar between pure grass diets and their respective mixed diets (Table 3 ) and that all diets met or exceeded NRC (2001) recommendations. Diets were offered as TMR for ad libitum intake, allowing for $10 \%$ orts on an as-fed basis according to the intake of the previous day, and TMR were regularly pushed back toward the cows during the day. During the experiment, the silages and haylage were sampled weekly. The samples were dried for $72 \mathrm{~h}$ at $55^{\circ} \mathrm{C}$ to determine $\mathrm{DM}$ concentration, and the com- 
Table 1. Ingredients of the experimental diets

\begin{tabular}{|c|c|c|c|c|c|}
\hline \multirow[b]{2}{*}{ Item, $\%$ of DM } & \multicolumn{5}{|c|}{$\operatorname{Diet}^{1}$} \\
\hline & TS & TFS & $\mathrm{TS}+\mathrm{AS}$ & $\mathrm{TFS}+\mathrm{AS}$ & $\mathrm{TFH}$ \\
\hline Timothy silage & 70.7 & - & 38.1 & - & - \\
\hline Tall fescue silage or haylage & - & 70.7 & - & 38.1 & 70.7 \\
\hline Alfalfa silage & - & - & 31.3 & 31.3 & - \\
\hline Ground corn & 23.4 & 23.4 & 26.9 & 26.9 & 23.4 \\
\hline Corn gluten meal & 2.7 & 2.7 & 2.2 & 2.2 & 2.7 \\
\hline Soybean meal & 1.8 & 1.8 & - & - & 1.8 \\
\hline Mineral-vitamin $\operatorname{mix}^{2}$ & 1.4 & 1.4 & 1.5 & 1.5 & 1.4 \\
\hline
\end{tabular}

position of the diets on an as-fed basis was adjusted accordingly. Water was added to TMR to target a $35 \%$ DM concentration. Cows had free access to water at all times during the experiment.

\section{Measurements and Sampling}

Amounts of feed offered and refused were recorded and diets were sampled on $\mathrm{d} 19,20$, and 21 of the experimental periods. During this 3 -d collection period, 1 sample of each silage used in the diets was also taken. All samples were stored at $-20^{\circ} \mathrm{C}$ for further analysis. Samples of diets were thawed and pooled by period to evaluate their respective particle size distribution using the Penn State Particle Separator (Kononoff and Heinrichs, 2003a). At $1300 \mathrm{~h}$, on $\mathrm{d}-3,-2$, and -1 of the first period, cows were weighed on a platform mounted on 4 load cells connected to an indicator (CI 2001 AS series, Kilotech, Lachine, QC, Canada).

For the 5 cows of one of the Latin squares, rumen fluid was collected from the ventral sac through a fistula on d 18 of each period at $0,1,2,4$, and $6 \mathrm{~h}$ relative to feeding time. A $10-\mathrm{mL}$ rumen fluid sample was collected as described by Baumann et al. (2016) and the $\mathrm{pH}$ immediately recorded (pHTestr 30, Oakton Instruments, Vernon Hills, IL). Rumen fluid samples

Table 2. Chemical composition and digestibility of the forages (mean \pm SD) used in the experimental diets $(n=5)$

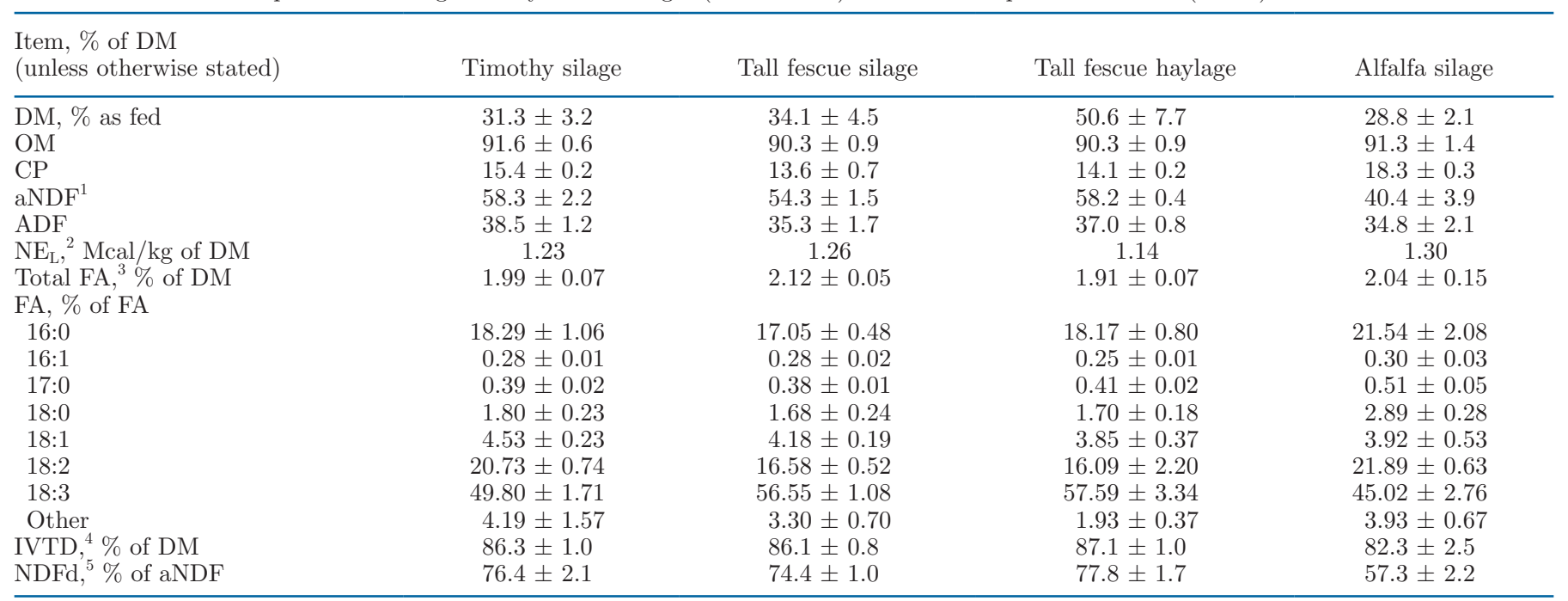

\footnotetext{
${ }^{1}$ Neutral detergent fiber assayed with a heat-stable amylase and sodium sulfite.

${ }^{2}$ Calculated based on the average chemical composition of each forage, according to NRC (2001).

${ }^{3}$ Fatty acid.

${ }^{4}$ In vitro true digestibility of DM.

${ }^{5}$ In vitro NDF digestibility.
} 
Table 3. Chemical composition, digestibility, and particle length (mean \pm SD) of the experimental diets $(n=5)$

\begin{tabular}{|c|c|c|c|c|c|}
\hline $\begin{array}{l}\text { Item, } \% \text { of DM } \\
\text { (unless otherwise stated) }\end{array}$ & \multicolumn{5}{|c|}{ Diet $^{1}$} \\
\hline \multicolumn{6}{|l|}{ Chemical composition } \\
\hline DM, \% as fed & $33.8 \pm 2.2$ & $34.1 \pm 4.1$ & $34.2 \pm 2.2$ & $34.7 \pm 2.0$ & $34.0 \pm 4.0$ \\
\hline $\mathrm{OM}$ & $92.4 \pm 0.2$ & $91.7 \pm 0.4$ & $92.8 \pm 0.2$ & $92.6 \pm 0.5$ & $91.2 \pm 0.6$ \\
\hline $\mathrm{CP}$ & $14.9 \pm 0.5$ & $13.8 \pm 0.4$ & $14.9 \pm 0.4$ & $13.9 \pm 0.6$ & $13.9 \pm 0.6$ \\
\hline aNDF & $43.8 \pm 1.5$ & $39.8 \pm 1.4$ & $37.7 \pm 0.9$ & $34.7 \pm 1.0$ & $45.2 \pm 1.6$ \\
\hline Total FA, ${ }^{3} \%$ of DM & $2.47 \pm 0.06$ & $2.44 \pm 0.08$ & $2.51 \pm 0.11$ & $2.48 \pm 0.11$ & $2.02 \pm 0.04$ \\
\hline \multicolumn{6}{|l|}{$\mathrm{FA}, \%$ of $\mathrm{FA}$} \\
\hline $16: 0$ & $17.32 \pm 0.21$ & $16.54 \pm 0.18$ & $18.12 \pm 0.38$ & $17.54 \pm 0.37$ & $18.59 \pm 0.71$ \\
\hline $16: 1$ & $0.24 \pm 0.04$ & $0.24 \pm 0.04$ & $0.25 \pm 0.03$ & $0.22 \pm 0.03$ & $0.28 \pm 0.10$ \\
\hline 18:0 & $2.04 \pm 0.05$ & $1.97 \pm 0.07$ & $2.33 \pm 0.15$ & $2.31 \pm 0.07$ & $2.20 \pm 0.08$ \\
\hline $18: 1$ & $12.98 \pm 0.40$ & $13.03 \pm 0.54$ & $13.36 \pm 0.68$ & $13.97 \pm 0.97$ & $13.57 \pm 0.89$ \\
\hline $18: 2$ & $35.52 \pm 0.59$ & $33.35 \pm 0.83$ & $35.94 \pm 1.03$ & $35.95 \pm 1.55$ & $32.55 \pm 1.20$ \\
\hline \multicolumn{6}{|l|}{ Digestibility } \\
\hline \multicolumn{6}{|c|}{$\begin{array}{l}\text { Particle length determinations, } \\
\% \text { of DM retained on sieves }\end{array}$} \\
\hline $19.0 \mathrm{~mm}$ & $73.2 \pm 5.2$ & $70.4 \pm 7.5$ & $67.2 \pm 4.9$ & $56.8 \pm 8.1$ & $83.2 \pm 3.9$ \\
\hline $8.0 \mathrm{~mm}$ & $16.3 \pm 4.4$ & $19.1 \pm 4.7$ & $22.1 \pm 5.7$ & $27.0 \pm 8.9$ & $7.5 \pm 3.6$ \\
\hline $4.0 \mathrm{~mm}$ & $7.4 \pm 3.1$ & $8.1 \pm 2.0$ & $8.1 \pm 1.6$ & $12.3 \pm 2.8$ & $4.5 \pm 1.4$ \\
\hline Pan & $3.0 \pm 1.4$ & $2.5 \pm 1.0$ & $2.9 \pm 0.7$ & $3.9 \pm 1.7$ & $4.8 \pm 3.1$ \\
\hline
\end{tabular}

${ }^{1} \mathrm{TS}=$ timothy silage $(100 \%) ; \mathrm{TFS}=$ tall fescue silage $(100 \%) ; \mathrm{TS}+\mathrm{AS}=$ timothy silage $(55 \%)$ and alfalfa silage $(45 \%) ;$ TFS + AS $=$ tall fescue silage $(55 \%)$ and alfalfa silage $(45 \%)$; TFH $=$ tall fescue haylage $(100 \%)$.

${ }^{2}$ Calculated based on the average chemical composition of each experimental diet, according to NRC (2001).

${ }^{3}$ Fatty acid.

${ }^{4}$ In vitro true digestibility of DM.

${ }^{5}$ In vitro NDF digestibility.

were then stabilized with $0.2 \mathrm{~mL}$ of $\mathrm{H}_{2} \mathrm{SO}_{4}(50 \%$, vol/ vol) and stored at $-20^{\circ} \mathrm{C}$ until determination of VFA and $\mathrm{NH}_{3}-\mathrm{N}$ concentrations.

Cows were milked at 0700 and $1700 \mathrm{~h}$ daily. Milk production was measured using calibrated milk meters (Flomaster Pro, DeLaval, Tumba, Sweden), and milk samples were collected at each milking from d 19 to 21 . Milk samples from the evening and morning milking were composited daily, proportionally to their respective milk yields. A composite milk sample was stored at $4^{\circ} \mathrm{C}$ with bronopol (2-bromo-2-nitropropane-1,3-diol) until further determination of fat, protein, lactose, and urea nitrogen. A second milk sample was collected and stored at $-20^{\circ} \mathrm{C}$ without preservative and further pooled by cow and period for subsequent fatty acid (FA) analysis.

\section{Chemical Analyses}

Before analysis, samples of the diets and silages were thawed at $4^{\circ} \mathrm{C}$, pooled by period (silages), by period and treatment (offers), or by period and cow (refusals), dried in a forced-air oven for $72 \mathrm{~h}$ at $55^{\circ} \mathrm{C}$ to determine
DM concentration, and ground to $1 \mathrm{~mm}$ using a Wiley mill (model 4, Arthur M. Thomas Co., Philadelphia, PA). All silage and diet samples were analyzed for residual moisture (AOAC International, 2005), OM (method 942.05, AOAC International, 2005), ADF (Ankom 2017a; AOAC International, 2005), neutral detergent fiber assayed with a heat-stable amylase and sodium sulfite and not corrected for residual ash (aNDF; Ankom 2017b; AOAC International, 2005), and $\mathrm{CP}(\mathrm{N} \times 6.25 ;$ AOAC International, 2005). Dietary FA were directly transesterified and FAME extracted as described by Villeneuve et al. (2013). Determination of dietary FA composition was carried out by gas chromatography, according to the method described by Fauteux et al. (2016). Both the in vitro true digestibility of DM (IVTD) and the in vitro NDF digestibility (NDFd) in feed samples were measured based on a 48-h incubation with buffered rumen fluid, followed by aNDF determination of the post-digestion residues (Goering and Van Soest, 1970). The rumen fluid incubation was performed with Ankom F57 filter bags and an Ankom Daisy II incubator, using the bath incubation procedures outlined by Ankom Technology 
(Ankom Technology, Macedon, NY). Rumen fluid was obtained from a ruminally fistulated dairy cow offered a diet of $37 \%$ grass silage, $15 \%$ corn silage, $8 \%$ hay, $30 \%$ corn grain, and $10 \%$ concentrate mix (DM basis) formulated to meet the nutritional requirements of a lactating dairy cow expected to produce $10,200 \mathrm{~kg}$ of milk/yr. The IVTD (g/ $\mathrm{kg}$ of DM) and the in vitro $\mathrm{NDFd}(\mathrm{g} / \mathrm{kg}$ of aNDF) were calculated as follows:

$$
\begin{aligned}
& \text { IVTD } \\
& =\left(1-\frac{\text { post-digestion dry weight following aNDF wash }}{\text { pre-digestion dry weight }}\right) \\
& \times 1,000 ; \\
& \text { NDFd } \\
& =\left(1-\frac{\text { post-digestion dry weight following aNDF wash }}{\text { pre-digestion dry weight of aNDF }}\right) \\
& \times 1,000 .
\end{aligned}
$$

Before the time of analysis, acidified samples of rumen fluid were thawed and centrifuged at 16,000 $\times$ $g$ for $15 \mathrm{~min}$ at $4^{\circ} \mathrm{C}$. The supernatant was analyzed for $\mathrm{NH}_{3}-\mathrm{N}$ as in Weatherburn (1967), using a Varioskan spectrophotometer (type 3001, cat. no. 5250010, Thermo Electron Corporation, Vantaa, Finland) at $625 \mathrm{~nm}$. Ruminal VFA concentrations were determined according to Weatherburn (1967) using a gas chromatograph (Clarus 680; Perkin Elmer, Waltham, MA) equipped with a polar capillary column (HP-Innowax 30-m length, 0.320-mm internal diameter, 0.25- $\mu \mathrm{m}$ film thickness; Agilent Technologies Canada Inc., Mississauga, ON, Canada) and a flame ionization detector. The split ratio was 25:1. At the time of sample injection, the column temperature was $80^{\circ} \mathrm{C}$, maintained for $0.5 \mathrm{~min}$, followed by a first increase to $180^{\circ} \mathrm{C}$ at $10^{\circ} \mathrm{C} /$ min and a second increase to $220^{\circ} \mathrm{C}$ at $30^{\circ} \mathrm{C} / \mathrm{min}$. The temperature was then maintained at $220^{\circ} \mathrm{C}$ for $2 \mathrm{~min}$.

Milk fat, protein, lactose, and MUN concentrations were determined according to AOAC method 972.160 (AOAC International, 2012), using an infrared procedure with a Foss MilkoScan FT 6000 by Valacta (SteAnne-de-Bellevue, QC, Canada). Fat- and energy-corrected milk yields were calculated based on milk yield and composition using the formulas of Gaines (1928) and Madsen et al. (2008), respectively. Milk lipid extraction and methylation of FA were performed according to procedures described by Chouinard et al. (1997). Milk FA profile was determined according to Boivin et al. (2013) using a gas chromatograph (Agilent 7890A, Agilent Technologies) equipped with a 100-m CP-Sil-88 capillary column $(0.25-\mathrm{mm}$ internal diameter, $0.20-\mu \mathrm{m}$ film thickness; Agilent Technologies) and a flame ionization detector.

\section{Statistical Analyses}

Data on DMI and milk production and composition were analyzed using the MIXED procedure of SAS (version 9.3, SAS Institute Inc., Cary, NC) as a triple $5 \times 5$ Latin square design, according to the following model:

$$
\mathrm{Y}_{\mathrm{ijkl}}=\mu+\mathrm{T}_{\mathrm{i}}+\mathrm{S}_{\mathrm{j}}+\mathrm{P}(\mathrm{S})_{\mathrm{k}: \mathrm{j}}+\mathrm{C}(\mathrm{S})_{\mathrm{l:j}}+\varepsilon_{\mathrm{ijk} \mathrm{l}},
$$

where $\mathrm{Y}_{\mathrm{ijkl}}=$ individual observation $(\mathrm{n}=75), \mu=$ overall mean, $\mathrm{T}_{\mathrm{i}}=$ fixed effect of treatment (i= 1 to 5$), \mathrm{S}_{\mathrm{j}}=$ fixed effect of square ( $\mathrm{j}=1$ to 3$), \mathrm{P}(\mathrm{S})_{\mathrm{k}: \mathrm{j}}=$ fixed effect of period ( $\mathrm{k}=1$ to 5$)$ within square, $\mathrm{C}(\mathrm{S})_{1: \mathrm{j}}=$ random effect of cow ( $1=1$ to 5 and $\mathrm{j}=1$ to 3 ) within square, and $\varepsilon_{\mathrm{ijkl}}=$ residual error term. Rumen fermentation parameters were analyzed for 1 Latin square with 5 fistulated animals, using the REPEATED statement in the MIXED procedure of SAS, using the following model:

$$
\mathrm{Y}_{\mathrm{ijkl}}=\mu+\mathrm{T}_{\mathrm{i}}+\mathrm{P}_{\mathrm{j}}+\mathrm{H}_{\mathrm{k}}+(\mathrm{T} \times \mathrm{H})_{\mathrm{ik}}+\mathrm{C}_{\mathrm{l}}+\varepsilon_{\mathrm{ijkl}},
$$

where $\mathrm{Y}_{\mathrm{ijkl}}=$ individual observation $(\mathrm{n}=75), \mu=$ overall mean, $\mathrm{T}_{\mathrm{i}}=$ fixed effect of treatment ( $\mathrm{i}=1$ to 5$), \mathrm{P}_{\mathrm{j}}$ = fixed effect of period $(\mathrm{j}=1$ to 5$), \mathrm{H}_{\mathrm{k}}=$ fixed effect of sampling time $(\mathrm{k}=0,1,2,4$, and $6 \mathrm{~h}$ postprandial $)$, $(\mathrm{T} \times \mathrm{H})_{\mathrm{ik}}=$ fixed effect of the interaction, $\mathrm{C}=$ random effect of cow $(1=1$ to 5$)$, and $\varepsilon_{\mathrm{ijk}}=$ residual error. Cow within period $\times$ treatment was the subject of the repeated statement. Because no treatment $\times$ sampling time interaction was observed, values for rumen parameters were averaged by day and analyzed according to the following model:

$$
\mathrm{Y}_{\mathrm{ijk}}=\mu+\mathrm{T}_{\mathrm{i}}+\mathrm{P}_{\mathrm{j}}+\mathrm{C}_{\mathrm{k}}+\varepsilon_{\mathrm{ijk}}
$$

where $\mathrm{Y}_{\mathrm{ijk}}=$ individual observation $(\mathrm{n}=25), \mu=$ overall mean, $\mathrm{T}_{\mathrm{i}}=$ fixed effect of treatment ( $\mathrm{i}=1$ to 5 ), $\mathrm{P}_{\mathrm{j}}=$ fixed effect of period ( $\mathrm{j}=1$ to 5$), \mathrm{C}=$ random effect of cow $(\mathrm{k}=1$ to 5$)$, and $\varepsilon_{\mathrm{ijk}}=$ residual error. For all models, the best covariance structure was selected based on the Akaike information criterion. Four preplanned contrasts were used to test the effects of the diets: (1) timothy versus tall fescue silage [TS + (TS + A) vs. TFS + (TFS + A); hereafter called "Species"]; (2) grass silage offered as sole forage or in combination with alfalfa silage $[\mathrm{TS}+\mathrm{TFS}$ vs. $(\mathrm{TS}+\mathrm{A})+(\mathrm{TFS}+$ A); hereafter called "Mixture"]; (3) interaction between grass silage species and grass:alfalfa silage mixtures; 
and (4) TFS versus TFH. Differences were declared significant at $P \leq 0.05$ and trends at $0.05<P \leq 0.10$.

\section{RESULTS AND DISCUSSION}

\section{DMI}

Grass species, offered either as sole silage or in combination with alfalfa silage, did not affect DMI (Table 4). This result is consistent with other studies, which found that DMI was similar for tall fescue and other grass species, provided that the grass species were harvested at the same stage of development (Fisher et al., 1993; Cherney et al., 2004). In another study, when comparing different grass species, Johansen et al. (2017b) established that DMI was related to silage OM digestibility. Accordingly, grass silages used in the current study had very similar IVTD and NDFd (Table 2). Regardless of the grass species, feeding grass silage in combination with alfalfa silage increased DMI by $7.5 \%$ compared with feeding only grass silage (Table 4). It is well established that DMI is greater when cows are fed forage legumes compared with forage grasses (Hoffman et al., 1998; Steinshamn, 2010; Johansen et al., 2018). According to Mertens (1994) and Hoffman et al. (1998), the difference in DMI is mainly explained by the lower NDF concentration in forage legumes than in forage grasses, the dietary NDF concentration being negatively correlated with DMI. In line with these observations, the aNDF concentration in the current experiment was greater in diets containing only grass silages (TS and TFS) than in diets with both grass and alfalfa silages (TS + A and TFS + A; Table 3), leading to a respective $9 \%$ increase in aNDF intake (Table 4). However, despite a lower aNDF concentration, IVTD of diets with both grass and alfalfa silages was numerically lower than grass silage diets, which could be explained by the lower NDFd of alfalfa compared with grass silages. Although it was not measured in this experiment, alfalfa is reported to have a greater rate of degradation (Hoffman et al., 1993) and rate of passage (Cherney et al., 2004) in the rumen than forage grasses. Substantial differences in the gross morphology and cellular structure between alfalfa and grasses can affect patterns of ingestion, mastication, rumination, and particle size reduction (Wilson and Kennedy, 1996; Dewhurst et al., 2003a,b), which can modify the passage rate and affect DMI.

Dry matter intake was also affected by the conservation method of tall fescue. Cows fed TFS consumed 8.7\% more DM than did cows fed TFH. The DM concentration of the tall fescue haylage and silage averaged 50.6 and $34.1 \%$, respectively (Table 2 ). In the current experiment, dietary DM was adjusted using water to obtain values ranging from 33.8 to $34.7 \%$ and standard deviations from 2.0 to $4.2 \%$ (Table 3 ). Thus, the variation in DMI between TFS and TFH could not be attributed to differences in DM concentration of the TMR. Huhtanen et al. (2007) considered multiple factors to predict forage consumption by dairy cows from forage characteristics. When comparing fresh-cut and wilted forages, they found a quadratic increase of forage consumption with increasing forage DM concentration, and, when considered alone, optimal values were obtained with a forage DM of $41.9 \%$. Fermentation characteristics and final chemical composition of silages can be affected by forage DM concentration and conservation type (Hristov and Sandev, 1998; McEniry et al., 2008), and when the former were included in the model, Huhtanen et al. (2007) found that the optimal forage DM concentration varied between 33.7 and $37.0 \%$. In contrast, when comparing grass-clover silages with varying $\mathrm{DM}$ concentration obtained through different wilting times, Johansen et al. (2017a) found that DMI was not affected by DM concentration of wilted silages. The differences in particle size of the diets (Table 3) could also explain the greater DMI observed with TFS compared with TFH. The proportion of particles retained on the $19-\mathrm{mm}$ sieve of the Penn State Particle Separator was approximately 13 percentage units greater in TFH than in TFS. Both TFS and TFH were chopped before either ensiling (silage) or TMR mixing (haylage). The differences in particle size are representative of the forages produced using these 2 conservation methods. Shorter particle size in silages and diets are reported to increase feed intake (Kononoff and Heinrichs, 2003b).

\section{Rumen Fermentation}

The rumen $\mathrm{pH}$ was similar between cows fed diets with timothy and tall fescue (Table 5). The relatively high values for rumen $\mathrm{pH}$ encountered in the current study $(>6.19)$ are in accordance with the high aNDF concentrations $(>34.7 \%)$ of the experimental diets. The molar proportion of propionate in the rumen was greater when cows were fed diets with tall fescue silage compared with timothy silage (Table 5), which resulted in a lower acetate-to-proprionate ratio. This effect could be linked to the lower aNDF concentration of tall fescue silage compared with timothy silage (54.3 vs. $58.3 \%$; Table 2).

Cows fed diets containing both grass and alfalfa silages had lower rumen $\mathrm{pH}$ compared with cows fed grass silage-based diets ( 6.23 vs. 6.38 ; Table 5 ). The greater proportion of ground corn (26.9 vs. $23.4 \%$; Table 1 ) and lower aNDF concentration (36.2 vs. $41.8 \%$; Table 3 ) of grass and alfalfa mixture diets compared with 
Richard et al.: TALL FESCUE AND LACTATION PERFORMANCE

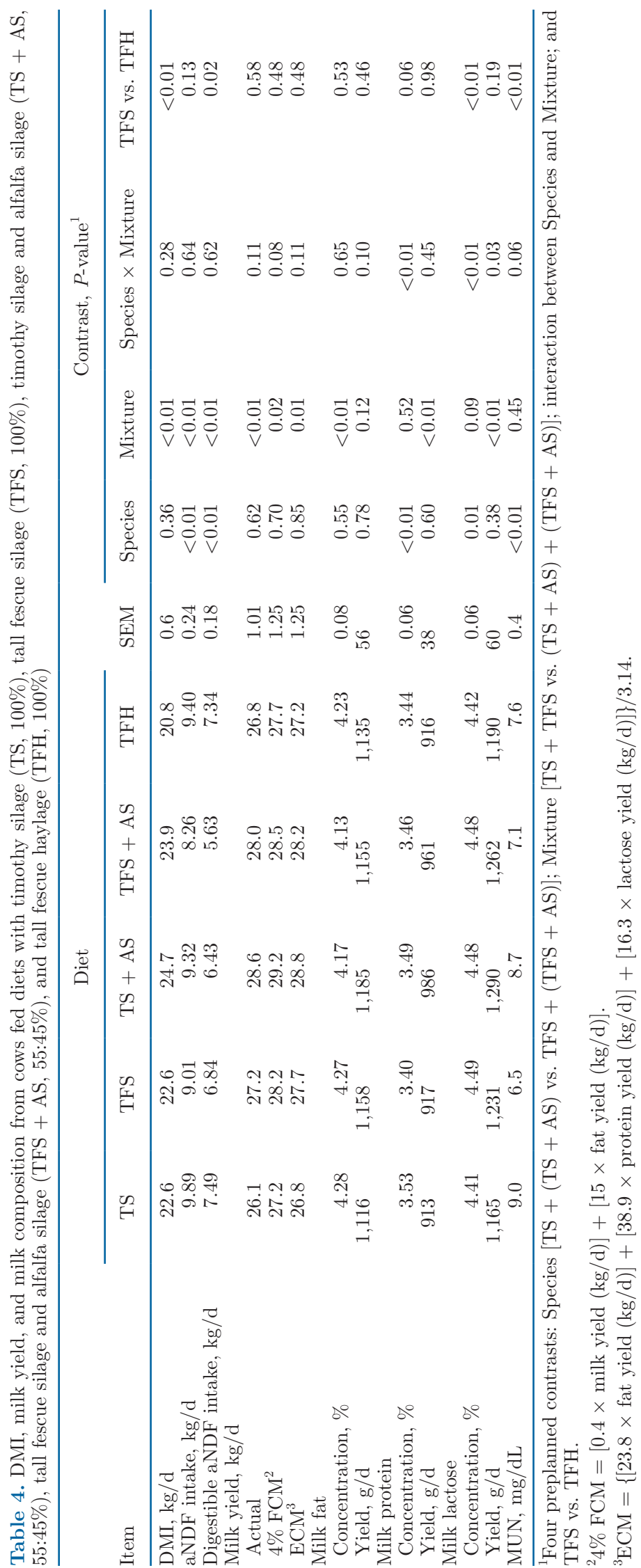




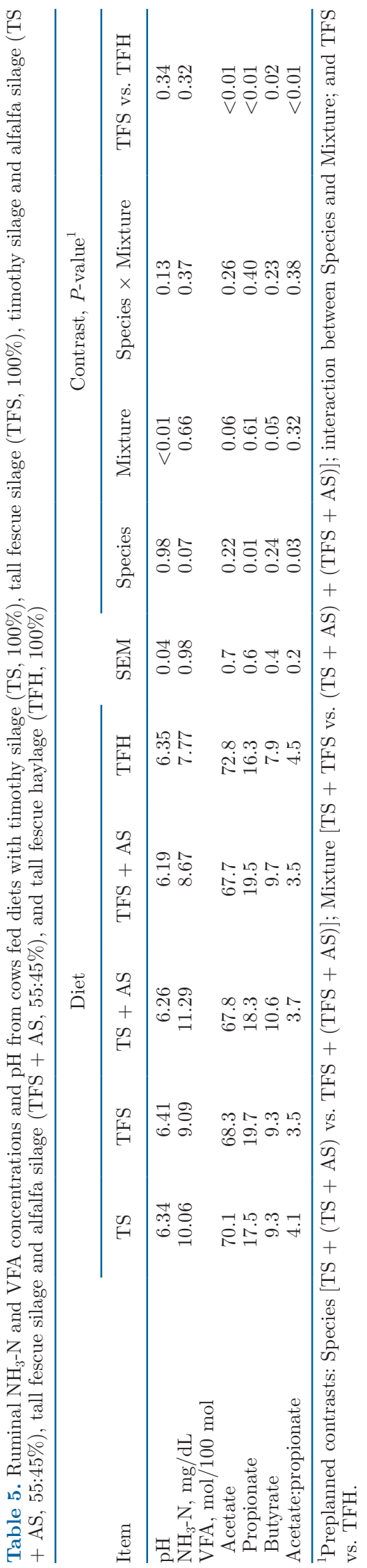

grass silage diets could explain this difference. It has long been recognized that increasing readily fermentable carbohydrates and decreasing fiber concentration of a diet can decrease rumen $\mathrm{pH}$ in dairy cows (Krause et al., 2002).

The rumen $\mathrm{pH}$ of cows fed diets with tall fescue as either silage or haylage did not differ (Table 5). However, feeding cows with TFH rather than TFS increased molar proportion of acetate and decreased molar proportion of propionate, leading to a higher acetate-topropionate ratio in rumen fluid (Table 5). In a previous study, Johansen et al. (2017a) found that DM concentration of grass-clover silage had no effect on rumen $\mathrm{pH}$ or concentrations of acetate or propionate in rumen fluid. However, as previously discussed, the TFH diet had a greater particle size than the THS diet, which could have reduced the rumen passage rate. A decrease in passage rate combined with the higher aNDF digestibility of TFH (Table 2) could have allowed for a more intense fibrolytic fermentation, leading to the observed changes in VFA profile with the absence of effect on rumen $\mathrm{pH}$.

\section{Milk Yield and Composition}

Grass species in silage-based diets did not affect the actual, fat-corrected, or energy-corrected milk yields, milk fat concentration and yield, or milk lactose yield (Table 4). Similarly, Cherney et al. (2004) did not detect any difference in milk yield and milk fat concentration for cows fed either tall fescue or orchardgrass silages when those 2 forage grasses were harvested at the recommended fiber concentration. This is consistent with a recent meta-analysis in which milk production in cows fed different grass species was found to be similar, provided that forage OM digestibility was similar (Johansen et al., 2018). In the current experiment, timothy and tall fescue silages had similar IVTD (86.2\% of DM; Table 2). Concentration of MUN was greater and that of rumen $\mathrm{NH}_{3}-\mathrm{N}$ tended to be greater $(P=0.07)$ in diets with timothy silage (TS and TS + A) than in diets with tall fescue silage (TFS and TFS + A; Tables 4 and 5), which could be due to the difference in $\mathrm{CP}$ concentration between the 2 silages (15.4 vs. $13.6 \%$; Table 2). This difference in CP concentration was reflected in the diets (14.9\% of CP for TS and TS $+\mathrm{AS}$, and $13.9 \%$ of CP for TFS and TFS + AS; Table 3) even though diets were formulated to have a similar $\mathrm{CP}$ concentration between pure grass diets and their respective mixed-forage diets. Similarly, milk protein concentration was greater when cows were fed the TS diet than the TFS diet, but similar when alfalfa silage was added to the diets (Table 4). This interaction suggests a shortage of $\mathrm{N}$ when tall fescue silage was the 
sole forage in the diet. Adding alfalfa silage might have improved the $\mathrm{N}$ balance, whereas this addition was not as beneficial when timothy silage was fed. Milk lactose concentration did not differ when cows were fed diets with timothy and tall fescue silages in combination with alfalfa silage, but it was lower with timothy silage than with tall fescue silage when those 2 silages were the only source of forage in the diet (Table 4).

Diets with tall fescue or timothy silages in combination with alfalfa silage resulted in lower milk fat concentration but greater milk yield than when only grass silages were included in the diet (Table 4). Therefore, fat-corrected and energy-corrected milk yields were also greater when AS complemented timothy or tall fescue silages in the forage proportion of the diets, despite a significant decrease in milk fat concentration. Moorby et al. (2009) also reported a decrease in milk fat concentration when the legume proportion was increased in the diet of dairy cows. Feeding grass silage in combination with alfalfa silage increased milk protein yield compared with the grass-only diets (Table 4). This difference might be attributed to an enhanced $\mathrm{N}$ use efficiency. Indeed, it has been shown that mixing legumes with grass silages improves microbial $\mathrm{N}$ flow to the duodenum in relation to the amount of dietary $\mathrm{N}$ consumed, resulting in an improved $\mathrm{N}$ use efficiency (Merry et al., 2006). Milk lactose yield was higher when cows were fed diets that included both grass and alfalfa silages compared with a diet with only a grass silage. This result could be linked with the higher milk production of cows fed grass silage in combination with alfalfa silage compared with diets with only a grass silage.

The lower DMI when cows were fed TFH rather than TFS did not affect the actual, fat-corrected, or energycorrected milk yields, milk fat concentration and yield, milk protein yield, or milk lactose yield (Table 4). Similar milk yield with a lower DMI resulted from a higher milk efficiency when cows were fed TFH compared with TFS. Similarly, TFH seems to have allowed for a greater metabolizable protein supply, as indicated by a higher MUN concentration and a tendency $(P=0.06)$ for greater milk protein concentration when cows were fed TFH compared with TFS (Table 4). A decrease in MUN concentration can be associated with a decrease in dietary CP (Broderick and Clayton, 1997) or an improved N use efficiency (Fadul-Pacheco et al., 2017). In the current experiment, where high-forage diets with similar concentrations of $\mathrm{CP}$ were fed to cows in midlactation (13.8 vs. $13.9 \%$ for the TFS and TFH diets, respectively), our results point to an improved forage $\mathrm{N}$ utilization when cows were fed TFH compared with TFS. Accordingly, Johansen et al. (2017a) observed that pre-wilting to a higher DM concentration increased metabolizable protein of grass-clover silage. They at- tributed this difference to a reduced degradation of feed protein, an increase in rumen microbial synthesis, and an increase in intestinal digestibility of amino acids when silage DM concentration was increased.

Apart from greater concentrations of FA originating from mammary de novo synthesis and consequent decreases in concentrations of preformed FA in milk from cows fed the TS + AS diet, diets had a limited effect on major milk FA concentrations (Table 6). This decrease in concentrations of preformed FA does not seem to originate from dietary FA, as diets had similar FA concentrations (\% of DM) and compositions (\% of FA; Table 3). However, feeding diets with grass species as sole forages increased the concentration of total milk branched-chain FA, and the amplitude of this increase was greater when cows were fed timothy silage than tall fescue silage. As previously mentioned, an increase was detected in the molar proportion of acetate-to-propionate ratio in the rumen for cows fed the timothy silage diets compared with the tall fescue diets, a greater $\mathrm{pH}$ in the rumen of cows fed the solely grass silage diets, and a concomitant tendency for an increase in the molar proportion of acetate (Table 5). These observations could be related to the potential effects of the respective aNDF concentration of the diets and its potential influence on microbial population in the rumen. A greater dietary aNDF concentration fosters the growth of cellulolytic bacteria in the rumen and is expected to increase the acetate proportion or, inversely, decrease the propionate proportion in the rumen (Beauchemin et al., 2008; Fievez et al., 2012). The dietary NDF concentration as well as the acetate-topropionate ratio in rumen fluid have been positively associated with most milk branched-chain FA (Vlaeminck et al., 2006). Accordingly, in the current experiment, milk fat concentrations of iso $14: 0$, anteiso $15: 0$, iso 16:0, iso 17:0, and anteiso 17:0 were greater when grass silage, and especially timothy silage, were fed as sole forages rather than with AS. Milk iso 15:0 concentration was also greater when timothy silage, and especially tall fescue silage, were fed as sole forages rather than in combination with AS. Milk fat concentration of branched-chain FA also increased when cows were fed TFH compared with TFS, which is in accordance with the increase in the molar proportion of acetate and the higher acetate-to-propionate ratio in rumen fluid. These results support the relationship between milk branched-chain FA and fermentation patterns occurring in the rumen.

\section{CONCLUSIONS}

Feeding established-lactation cows with tall fescue or timothy silages, offered either as the sole forage source 
Richard et al.: TALL FESCUE AND LACTATION PERFORMANCE

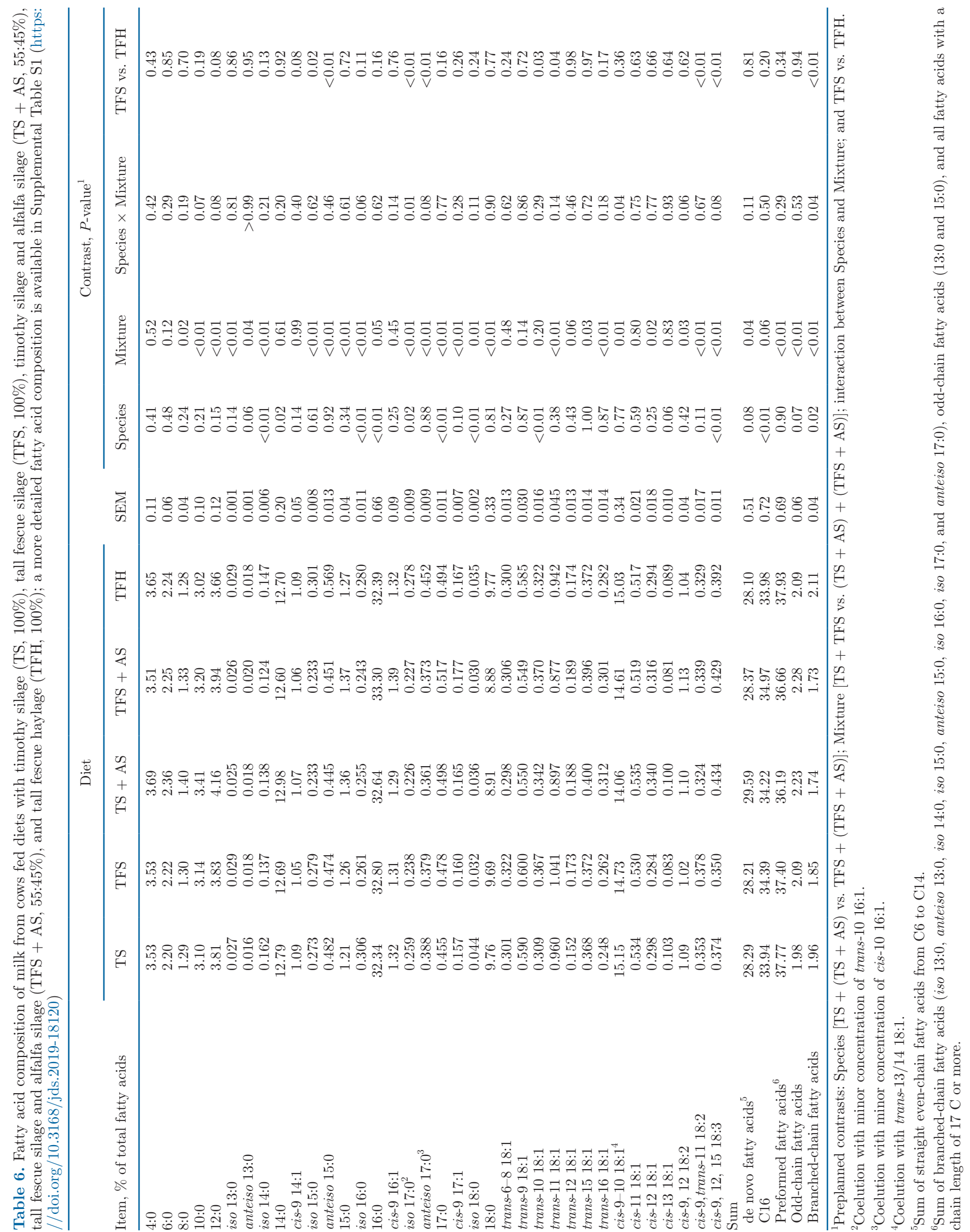


in the diet or in combination with alfalfa silage, did not affect DMI, milk yield, or milk fat concentration. Feeding tall fescue or timothy grass silage in combination with alfalfa silage resulted in higher DMI and milk yield but lower milk fat concentration than feeding these silages as the sole forage source in the diet. Milk protein concentration was not affected by grass species when the grass silage was offered in combination with alfalfa silage, but was higher with timothy than tall fescue silage when they were offered as the forage source in the diet. Diets with tall fescue haylage rather than tall fescue silage resulted in lower DMI but similar milk yield and milk fat concentration, which suggests a greater feed use efficiency for cows fed tall fescue haylage. Our results confirm the potential of using tall fescue silage or haylage to replace timothy silage in dairy cow diets.

\section{ACKNOWLEDGMENTS}

This experiment was funded by a concerted action involving the Fonds de recherche du Québec - Nature et technologies (FRQNT; Québec, QC, Canada), the Ministère de l'Agriculture, des Pêcheries et de l'Alimentation du Québec, and Novalait Inc. (Québec, QC, Canada), with a contribution from the Centre de Recherche en Sciences Animales de Deschambault (Deschambault, QC, Canada). The authors thank Micheline Gingras and Yolaine Lebeuf from Université Laval (Québec, QC, Canada) and Geneviève Bégin and Camille Lambert-Beaudet from Agriculture and AgriFood Canada (Ottawa) for professional and technical assistance, Annie Dumas for her help in organizing the experiment at the farm, and André Perreault, Jonathan Moreau, Michaël Benoit, and Sébastien Coursol for their work in the barn at the Centre de Recherche en Sciences Animales de Deschambault. The authors have not stated any conflicts of interest.

\section{REFERENCES}

Ankom. 2017a. Technology method 12. ADF in feeds-filter bag technique. Accessed Mar. 14, 2018. https://www.ankom.com/sites/ default/files/documentfiles/Method_12_ADF_A2000.pdf.

Ankom. 2017b. Technology method 13. NDF in feeds-filter bag technique. Accessed Mar. 14, 2018. https://www.ankom.com/sites/ default/files/document-files/Method_13_NDF_A2000.pdf.

AOAC International. 2005. Official Methods of Analysis, 18th ed. AOAC International, Arlington, VA.

AOAC International. 2012. Official Methods of Analysis, 19th ed. AOAC International, Arlington, VA.

Baumann, E., P. Y. Chouinard, Y. Lebeuf, D. E. Rico, and R. Gervais. 2016. Effect of lipid supplementation on milk odd-and branchedchain fatty acids in dairy cows. J. Dairy Sci. 99:6311-6323. https: //doi.org/10.3168/jds.2015-10746.

Beauchemin, K. A., M. Kreuzer, F. O'mara, and T. A. McAllister. 2008. Nutritional management for enteric methane abatement: A review. Aust. J. Exp. Agric. 48:21-27. https://doi.org/10.1071/ EA07199.

Bélanger, G., Y. Castonguay, A. Bertrand, C. Dhont, P. Rochette, L. Couture, R. Drapeau, D. Mongrain, F. P. Chalifour, and R. Michaud. 2006. Winter damage to perennial forage crops in eastern Canada: Causes, mitigation, and prediction. Can. J. Plant Sci. 86:33-47. https://doi.org/10.4141/P04-171.

Bélanger, G., Y. Castonguay, and J. Lajeunesse. 2014. Benefits of mixing timothy with alfalfa for forage yield, nutritive value, and weed suppression in northern environments. Can. J. Plant Sci. 94:51-60. https://doi.org/10.4141/cjps2013-228.

Bertrand, A., G. F. Tremblay, S. Pelletier, Y. Castonguay, and G. Bélanger. 2008. Yield and nutritive value of timothy as affected by temperature, photoperiod and time of harvest. Grass Forage Sci. 63:421-432. https://doi.org/10.1111/j.1365-2494.2008.00649.x.

Boivin, M., R. Gervais, and P. Y. Chouinard. 2013. Effect of grain and forage fractions of corn silage on milk production and composition in dairy cows. Animal 7:245-254. https://doi.org/10.1017/ S1751731112001486.

Brito, A. F., G. F. Tremblay, A. Bertrand, Y. Castonguay, G. Bélanger, R. Michaud, H. Lapierre, C. Benchaar, H. V. Petit, D. R. Ouellet, and R. Berthiaume. 2008. Alfalfa cut at sundown and harvested as baleage improves milk yield of late-lactation dairy cows. J. Dairy Sci. 91:3968-3982. https://doi.org/10.3168/jds.2008 $-1282$.

Broderick, G. A., and M. K. Clayton. 1997. A statistical evaluation of animal and nutritional factors influencing concentrations of milk urea nitrogen. J. Dairy Sci. 80:2964-2971. https://doi.org/10 .3168/jds.S0022-0302(97)76262-3.

Cherney, D. J., J. H. Cherney, and L. E. Chase. 2004. Lactation performance of Holstein cows fed fescue, orchardgrass, or alfalfa silage. J. Dairy Sci. 87:2268-2276. https://doi.org/10.3168/jds .S0022-0302(04)70047-8.

Chouinard, P. Y., J. Lévesque, V. Girard, and G. Brisson. 1997. Dietary soybeans extruded at different temperatures: Milk composition and in situ fatty acid reactions. J. Dairy Sci. 80:2913-2924. https://doi.org/10.3168/jds.S0022-0302(97)76257-X.

Dewhurst, R. J., R. T. Evans, N. D. Scollan, J. M. Moorby, R. J. Merry, and R. J. Wilkins. 2003a. Comparison of grass and legume silages for milk production. 2. In vivo and in sacco evaluations of rumen function. J. Dairy Sci. 86:2612-2621. https://doi.org/10 .3168/jds.S0022-0302(03)73856-9.

Dewhurst, R. J., W. J. Fisher, J. K. S. Tweed, and R. J. Wilkins. 2003b. Comparison of grass and legume silages for milk production. 1. Production responses with different levels of concentrate. J. Dairy Sci. 86:2598-2611. https://doi.org/10.3168/jds.S0022 -0302(03)73855-7.

Drapeau, R., G. Bélanger, G. F. Tremblay, and R. Michaud. 2005. Rendement et valeur nutritive de la fétuque élevée cultivée en régions à faibles degrés-jours de croissance (Yield and nutritive value of tall fescue grown in low growing degree-day areas). Can. J. Plant Sci. 85:369-376. https://doi.org/10.4141/P04-106

Fadul-Pacheco, L., D. Pellerin, P. Y. Chouinard, M. A. Wattiaux, M. Duplessis, and E. Charbonneau. 2017. Nitrogen efficiency of eastern Canadian dairy herds: Effect on production performance and farm profitability. J. Dairy Sci. 100:6592-6601. https://doi.org/10 .3168/jds.2016-11788.

Fauteux, M. C., R. Gervais, D. E. Rico, Y. Lebeuf, and P. Y. Chouinard. 2016. Production, composition, and oxidative stability of milk highly enriched in polyunsaturated fatty acids from dairy cows fed alfalfa protein concentrate or supplemental vitamin E. J. Dairy Sci. 99:4411-4426. https://doi.org/10.3168/jds.2015-10722.

Fievez, V., E. Colman, J. M. Castro-Montoya, I. Stefanov, and B. Vlaeminck. 2012. Milk odd- and branched-chain fatty acids as biomarkers of rumen function-An update. Anim. Feed Sci. Technol. 172:51-65. https://doi.org/10.1016/j.anifeedsci.2011.12.008.

Fisher, L. J., S. Bittman, D. E. Hunt, J. A. Shelford, and B. D. Mason. 1993. A comparison of tall fescue and orchardgrass silages for lactating cows. Can. J. Anim. Sci. 73:907-914. https://doi.org/10 .4141/cjas93-092. 
Gaines, W. L. 1928. The energy basis of measuring milk yield in dairy cows. Illinois Agric. Exp. Stn. Bull. 308. https://doi.org/10.3168/ jds.2018-15022.

Goering, H. K., and P. J. Van Soest. 1970. Forage fiber analyses (apparatus, reagents, procedures, and some applications). USDA Agric. Handb. 379:20.

Hoffman, P. C., D. K. Combs, and M. D. Casler. 1998. Performance of lactating dairy cows fed alfalfa silage or perennial ryegrass silage. J. Dairy Sci. 81:162-168. https://doi.org/10.3168/jds.S0022 -0302(98)75563-8.

Hoffman, P. C., S. J. Sievert, R. D. Shaver, D. A. Welch, and D. K. Combs. 1993. In situ dry matter, protein, and fiber degradation of perennial forages. J. Dairy Sci. 76:2632-2643. https://doi.org/10 .3168/jds.S0022-0302(93)77599-2.

Hristov, A. N., and S. G. Sandev. 1998. Proteolysis and rumen degradability of protein in alfalfa preserved as silage, wilted silage or hay. Anim. Feed Sci. Technol. 72:175-181. https://doi.org/10.1016/ S0377-8401(97)00177-6.

Huhtanen, P., M. Rinne, and J. Nousiainen. 2007. Evaluation of the factors affecting silage intake of dairy cows: A revision of the relative silage dry-matter intake index. Animal 1:758-770. https://doi .org/10.1017/S175173110773673X.

Johansen, M., A. L. F. Hellwing, P. Lund, and M. R. Weisbjerg. 2017a. Metabolisable protein supply to lactating dairy cows increased with increasing dry matter concentration in grass-clover silage. Anim. Feed Sci. Technol. 227:95-106. https://doi.org/10.1016/j .anifeedsci.2017.02.018.

Johansen, M., P. Lund, and M. R. Weisbjerg. 2018. Feed intake and milk production in dairy cows fed different grass and legume species: A meta-analysis. Animal 12:66-75. https://doi.org/10.1017/ S1751731117001215.

Johansen, M., K. Søegaard, P. Lund, and M. R. Weisbjerg. 2017b. Digestibility and clover proportion determine milk production when silages of different grass and clover species are fed to dairy cows. J. Dairy Sci. 100:8861-8880. https://doi.org/10.3168/jds.2017-13401.

Kononoff, P. J., and A. J. Heinrichs. 2003a. The effect of corn silage particle size and cottonseed hulls on cows in early lactation. J. Dairy Sci. 86:2438-2451. https://doi.org/10.3168/jds.S0022 $-0302(03) 73838-7$.

Kononoff, P. J., and A. J. Heinrichs. 2003b. The effect of reducing alfalfa haylage particle size on cows in early lactation. J. Dairy Sci. 86:1445-1457. https://doi.org/10.3168/jds.S0022-0302(03)73728 $-\mathrm{X}$.

Krause, K. M., D. K. Combs, and K. A. Beauchemin. 2002. Effects of forage particle size and grain fermentability in midlactation cows. II. Ruminal pH and chewing activity. J. Dairy Sci. 85:1947-1957. https://doi.org/10.3168/jds.S0022-0302(02)74271-9.

Madsen, T. G., M. O. Nielsen, J. B. Andersen, and K. L. Ingvartsen. 2008. Continuous lactation in dairy cows: Effect on milk production and mammary nutrient supply and extraction. J. Dairy Sci. 91:1791-1801. https://doi.org/10.3168/jds.2007-0905.

McEniry, J., P. O'kiely, N. J. W. Clipson, P. D. Forristal, and E. M. Doyle. 2008. The microbiological and chemical composition of silage over the course of fermentation in round bales relative to that of silage made from unchopped and precision-chopped herbage in laboratory silos. Grass Forage Sci. 63:407-420. https://doi.org/10 .1111/j.1365-2494.2008.00645.x.

Merry, R. J., M. R. F. Lee, D. R. Davies, R. J. Dewhurst, J. M Moorby, N. D. Scollan, and M. K. Theodorou. 2006. Effects of high-sugar ryegrass silage and mixtures with red clover silage on ruminant digestion. 1 . In vitro and in vivo studies of nitrogen utilization. J. Anim. Sci. 84:3049-3060. https://doi.org/10.2527/ jas.2005-735.

Mertens, D. R. 1994. Regulation of forage intake. Page 450 in Forage Quality, Evaluation, and Utilization. G. C. Fahey, Jr., ed. Am. Soc. Agro., Madison, WI.

Moorby, J. M., M. R. F. Lee, D. R. Davies, E. J. Kim, G. R. Nute, N. M. Ellis, and N. D. Scollan. 2009. Assessment of dietary ratios of red clover and grass silages on milk production and milk quality in dairy cows. J. Dairy Sci. 92:1148-1160. https://doi.org/10.3168/ jds.2008-1771.

NRC. 2001. Nutrient Requirements of Dairy Cattle. 7th rev. ed. National Academy Press, Washington, DC.

Olfert, E. D., B. M. Cross, and A. A. McWilliam. 1993. Canadian Council on Animal Care: Guide to the care and use of experimental animals. Accessed Mar. 14. 2018. https://www.ccac.ca/ Documents/Standards/Guidelines/Experimental_Animals_Vol1 .pdf.

Peratoner, G., C. Florian, C. Klotz, U. Figl, and S. Gottardi. 2011. Effect of forage conservation on the leaf texture of tall fescue. Pages 223-225 in Grassland Farming and Land Management Systems in Mountainous Regions. Proceedings of the 16th Symposium of the European Grassland Federation, Gumpenstein, Austria, Aug. 29-31, 2011. Agricultural Research and Education Center (AREC) Raumberg-Gumpenstein, Austria.

Pomerleau-Lacasse, F., P. Seguin, G. F. Tremblay, G. Bélanger, J. Lajeunesse, and E. Charbonneau. 2019. Alternatives to timothy grown in mixture with alfalfa in eastern Canada. Agron. J. 111:314-327. https://doi.org/10.2134/agronj2018.05.0309.

Qian, B., R. De Jong, S. Gameda, T. Huffman, D. Neilsen, R. Desjardins, H. Wang, and B. McConkey. 2013. Impact of climate change scenarios on Canadian agroclimatic indices. Can. J. Soil Sci. 93:243-259. https://doi.org/10.4141/cjss2012-053.

Steinshamn, H. 2010. Effect of forage legumes on feed intake, milk production and milk quality-A review. Anim. Sci. Pap. Rep. 28:195-206.

Villeneuve, M.-P., Y. Lebeuf, R. Gervais, G. F. Tremblay, J. C. Vuillemard, J. Fortin, and P. Y. Chouinard. 2013. Milk volatile organic compounds and fatty acid profile in cows fed timothy as hay, pasture, or silage. J. Dairy Sci. 96:7181-7194. https://doi.org/10 $.3168 /$ jds.2013-6785.

Vlaeminck, B., V. Fievez, A. R. J. Cabrita, A. J. M. Fonseca, and R. J. Dewhurst. 2006. Factors affecting odd- and branched-chain fatty acids in milk: A review. Anim. Feed Sci. Technol. 131:389-417. https://doi.org/10.1016/j.anifeedsci.2006.06.017.

Weatherburn, M. W. 1967. Phenol-hypochlorite reaction for determination of ammonia. Anal. Chem. 39:971-974. https://doi.org/10 $.1021 /$ ac60252a045.

Wilson, J. R., and P. M. Kennedy. 1996. Plant and animal constraints to voluntary feed intake associated with fibre characteristics and particle breakdown and passage in ruminants. Aust. J. Agric. Res. 47:199-225. https://doi.org/10.1071/AR9960199.

\section{ORCIDS}

R. Gervais ๑ https://orcid.org/0000-0002-6929-2027

G. F. Tremblay 10 https://orcid.org/0000-0001-7652-8985

G. Bélanger (1) https://orcid.org/0000-0001-5923-7625

É. Charbonneau @ https://orcid.org/0000-0002-0675-3076 